\title{
The effect of dietary protein deprivation on protein synthesis in the isolated liver parenchymal cell
}

\author{
BY ANNE G. GRANT* AND \\ R. HOFFENBERG $\dagger$ \\ Department of Clinical Investigation, MRC Clinical Research Centre, \\ Harrow, Middlesex
}

(Received 12 November 1976 - Accepted 10 March 1977)

1. Parenchymal cells were isolated from the liver of rats that had been deprived of dietary protein for 3 weeks.

2. The cells were two-thirds the diameter of those derived from livers of normal animals and consumed oxygen at a rate of $16 \cdot 2 \pm 2 \cdot 7 \mu \mathrm{l} / \mathrm{h}$ per $10^{8}$ viable cells, half the normal value.

3. Albumin and transferrin were synthesized at rates of $0.94 \pm 0.12$ and $0.60 \pm 0.07 \mu \mathrm{g} / \mathrm{h}$ per $10^{6}$ viable cells respectively and urea at a rate of $0.77 \pm 0.12 \mu \mathrm{g} / \mathrm{h}$ per $10^{6}$ cells. This represents a $25-50 \%$ decrease in the rates of synthesis measured in cells isolated from normal livers.

4. The results are discussed in relation to the long-term effects of malnutrition on liver cell function.

A reduction in albumin synthesis rate following long-term dietary protein deprivation has been demonstrated in man and experimental animals (James \& Hay, 1968; Kirsch, Frith, Black \& Hoffenberg, 1968; Haider \& Tarver, 1969; Morgan \& Peters, 1971) and in studies using the isolated, perfused rat liver (Hoffenberg, Gordon \& Black, 1971; Tavill, East, Black, Nadkarni \& Hoffenberg, 1973), but the responsible factors are not easily identified because of the complex changes that occur during malnutrition.

Reduction in the amount of protein produced by an organ could arise because fewer cells are engaged in protein synthesis or because each cell produces less. Evidence in support of the former mechanism of control has been provided by a fluorescent-antibody technique (Chandrasakharam, Fleck \& Munro, 1967), but these studies may simply reflect the filling and emptying of protein-storage channels in the endoplasmic reticulum. In contrast, the reduction in cellular protein (Wikramanayake, Heagy \& Munro, 1953; Wannemacher, Wannemacher \& Yatvin, 1971) that is found after protein deprivation would seem to reflect a uniform reduction in the rate of protein synthesis.

Earlier studies in this laboratory showed it was possible to assess albumin synthesis at a single-cell level (East, Louis \& Hoffenberg, 1973; Grant \& Black, 1974) and we now wish to report a comparative study of protein synthesis by cells taken from the livers of normal and protein-deprived (PD) animals.

\section{Experimental procedure}

Parenchymal cells were isolated from the livers of male rats of the Sprague-Dawley strain by the method previously described (East et al. 1973). Animals maintained on a normal diet (Porton rat diet, Christopher Hill Group, Poole, Dorset) weighed 280-330 g at the time of experimentation. Those on a protein-free diet (Hoffenberg, Gordon, Black \& Louis, 1970) for a period of $21 \mathrm{~d}$ did not gain weight on this regimen and weighed 200-260 g. Both groups had been allowed unrestricted access to food and water throughout the study.

Portions of liver cell suspension containing $10-12 \times 10^{8}$ cells $/ \mathrm{ml}$ were placed in flasks and

* Present address: Department of Surgery, St George's Hospital Medical School, Cranmer Terrace, Tooting, London SW17 ORE.

$\dagger$ Present address: Department of Medicine, Queen Elizabeth Hospital, Birmingham B15 2TH. 
incubated in a Warburg apparatus at $37^{\circ}$ in air or under a constant supply of oxygen-carbon dioxide $(95: 5, \mathrm{v} / \mathrm{v})$ for up to $3 \mathrm{~h}$. Two flasks were removed each hour for sampling in duplicate. Media used for incubation were Eagle's basal essential medium (BEM; containing the minimum concentration of essential amino acids necessary for tissue culture (Eagle, 1955)), Eagle's minimal essential medium (MEM; containing twice the concentration of amino acids present in BEM (Eagle, 1959)) and calcium-free Krebs-Ringer phosphate (KRP; supplemented with amino acids to physiological rat serum levels (East et al. 1973)). Non-essential amino acids (Flow Laboratories, Irvine, Scotland) were added to BEM and MEM in multiples of the minimum concentration where indicated. Hepes buffer ( $N$-2-hydroxyethylpeperazine- $N^{\prime}$-2-ethanesulphonic acid) (Sigma Chemical Co., St Louis, Mo., USA) was added to BEM and MEM to a final concentration of $20 \mathrm{mM}$.

Cell viability was determined by trypan-blue exclusion (Howard \& Pesch, 1968). Albumin and transferrin production were measured by quantitative radial immunodiffusion against a specific antiserum as described previously (Mancini, Carbonara \& Heremans, 1965; East et al. 1973; Grant \& Black, 1974). Specific antiserum to rat transferrin was prepared in goats using transferrin separated from rat plasma by DEAE-cellulose (Whatman Biochemicals Ltd, Maidstone, Kent), Sephadex G-150 (Pharmacia, Uppsala, Sweden) and polyacrylamide-gel electrophoresis (Ramsden \& Louis, 1973). Specificity of the antisera and purity of the standards were checked by Laurell crossed-immunoelectrophoresis (MinchinClarke \& Freeman, 1968) against whole rat serum and incubation samples (East et al. 1973). Cell diameter, of a random selection of cells which excluded trypan blue, was measured microscopically using a calibrated graticule (Leitz, Wetzlar, Germany), and cell volume was estimated from the packed cell volume of each cell suspension. The urea concentration of the supernatant fluid was measured using an AutoAnalyzer (Mark 2; Technicon Instruments Co. Ltd, Basingstoke, Hants).

\section{RESULTS}

Comparison of cell size, viability and rates of $\mathrm{O}_{2}$ consumption

$\mathrm{O}_{2}$ consumption by parenchymal cells isolated from livers of normal and PD rats and incubated in KRP is shown in Fig. 1. Both cell types maintained a linear rate of $\mathrm{O}_{2}$ consumption after the first hour of incubation but those from PD rats consumed $\mathrm{O}_{2}$ at a rate of (mean $\pm \mathrm{SE} ; \mu \mathrm{l} / \mathrm{h}$ per $10^{6}$ viable cells) $16 \cdot 2 \pm 2 \cdot 7$ compared to $33 \cdot 3 \pm 2 \cdot 8$ for normal cells $(P<0.001)$.

Based on their ability to exclude trypan blue (East et al. 1973), at least $60 \%$ of the cells were initially viable. Cell viability decreased by $10 \%$ in the $3 \mathrm{~h}$ period of incubation but was not altered by protein deprivation.

Cells isolated from PD animals were found to have a modal diameter of $18 \mu \mathrm{m}$, two-thirds the value found for normal liver cells (Fig. 2). Packed cell volume was reduced by almost $50 \%$ and the marked difference in cell size was also visible by phase-contrast microscopy (plate 1).

\section{Comparison of rates of albumin, transferrin and total protein production}

Albumin and transferrin production by liver cells from normal and PD rats incubated in BEM is shown in Fig. 3. The results of albumin production by normal cells incubated in BEM have already been reported (Grant \& Black, 1974) but are included here for comparison. Cells from PD rats maintained linear protein production at rates of (mean $\pm \mathrm{SE}$ ) $0.94 \pm 0.12$ and $0.60 \pm 0.07 \mu \mathrm{g} / \mathrm{h}$ per $10^{6}$ viable cells for albumin and transferrin respectively. These rates of protein production were significantly lower than those found on incubation of normal liver cells $\left((\right.$ mean $\pm \mathrm{SE})$ albumin $1.95 \pm 0.20$, transferrin $1.54 \pm 0.11 \mu \mathrm{g} / \mathrm{h}$ per $10^{6}$ viable cells; $P<0.005$ in both instances). The amounts of albumin and transferrin found in 


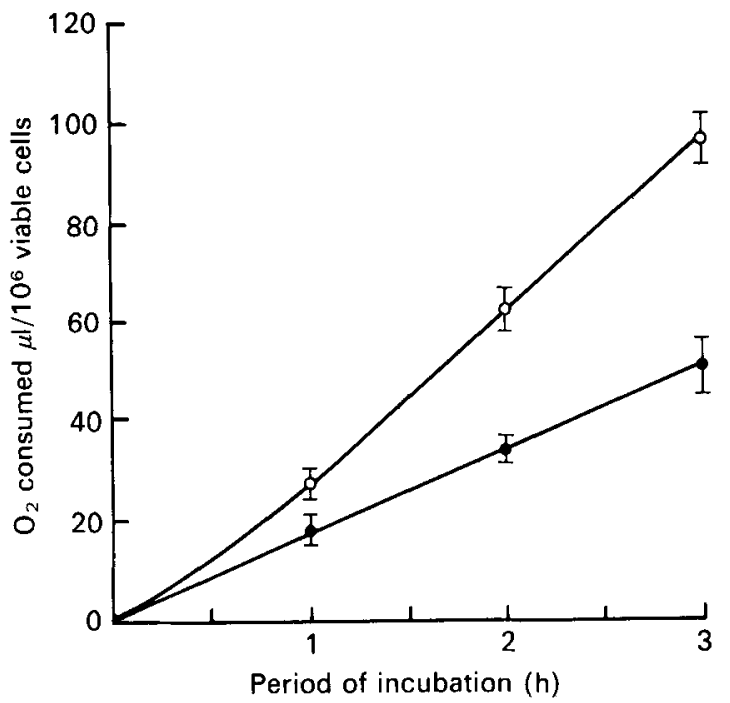

Fig. 1. Oxygen consumption by liver cells from normal ( $\mathrm{O}-\mathrm{O}$; six experiments) and proteindeprived (O-O ; four experiments) rats incubated in Krebs-Ringer phosphate. $\mathrm{O}_{2}$ uptake was measured using a manometer (for details of dietary treatments and experimental procedures, see p. 255). Results are expressed as mean viable cell count for each $1 \mathrm{~h}$ period. The points represent mean values with their standard errors indicated as vertical bars.

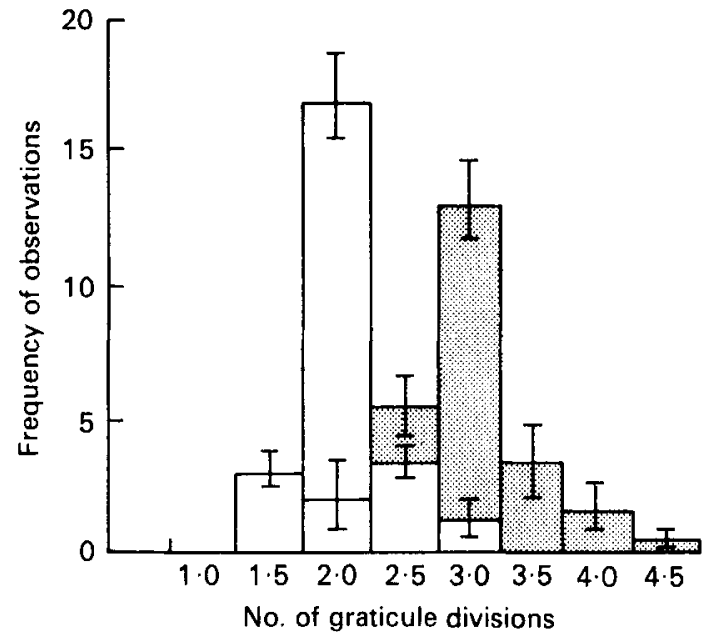

Fig. 2. Size of cells isolated from livers of normal (国; four experiments) and protein-deprived (PD) ( $\square$; six experiments) rats (for details of dietary treatments, see p. 255). One graticule division is equivalent to $9.4 \mu \mathrm{m}$. Modal diameters of PD and normal cells were equivalent to 18 and $28 \mu \mathrm{m}$ respectively. The results are mean values with their standard errors indicated by vertical bars.

the cells at the beginning of incubation was also reduced. Supplementation of the incubation medium with essential or non-essential amino acids did not increase the rate of protein synthesis.

\section{Comparison of rates of urea synthesis}

Cells isolated from PD rats produced urea at a rate of $0.77 \pm 0.12 \mu \mathrm{g} / \mathrm{h}$ per $10^{8}$ cells (Fig. 4), almost one-quarter of that found in normal cells $\left(3.20 \pm 0.24 \mu \mathrm{g} / \mathrm{h}\right.$ per $10^{6}$ cells; $P<0.001)$. Supplementation of the incubation medium with both essential and non- 


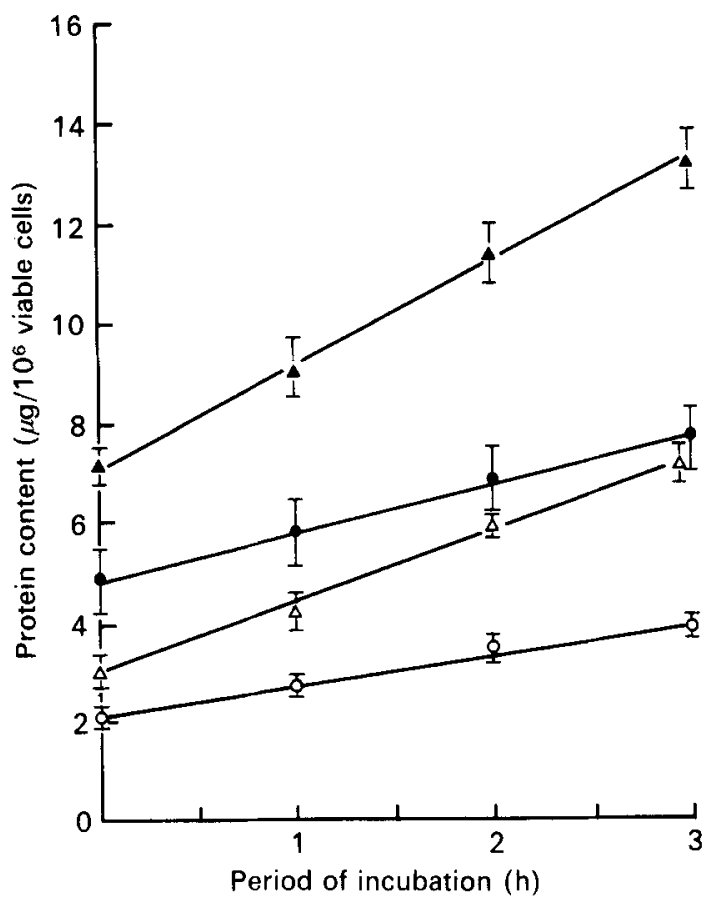

Fig. 3. Albumin and transferrin production by cells from normal and protein-deprived (PD) rats incubated in Eagle's basal essential medium (for details of dietary treatments and experimental procedures, see p. 255). Results are expressed as mean viable cell count for each $1 \mathrm{~h}$ period. Albumin: $\mathbf{A}-\mathbf{\Lambda}$, normal cells, twelve experiments; $-\mathbf{-}$, PD cells, eleven experiments; transferrin: $\triangle-\triangle$, normal cells, five experiments; $O-O$, PD cells, five experiments. The basal level of protein in cells from PD animals was lower than that of normal rats. The points represent mean values with their standard errors indicated as vertical bars.

essential amino acids only fractionally increased the rate of synthesis (Fig. 4). Urea production at zero time was too low to permit a measurement to be made at this point.

\section{DISCUSSION}

The isolated cell provides a useful model for in vitro studies of adaptation to dietary protein deprivation.

Our results showed that parenchymal cells isolated from the livers of normal animals have a mean diameter of $28 \mu \mathrm{m}$, a value in agreement with earlier reports (Weibel, Stäubi, Gnägi \& Hess, 1969; Wanson, Mosselmans \& Baudhuin, 1973), while those taken from rats deprived of dietary protein for $21 \mathrm{~d}$ (PD rats) showed a significantly smaller diameter $(18 \mu \mathrm{m})$ and volume, despite the relatively inaccurate nature of these measurements. This was in keeping with the reduction in liver and body-weight found in these animals (Hoffenberg et al. 1971; Morgan \& Peters, 1971). The $50 \%$ reduction in $\mathrm{O}_{2}$ consumption found in these cells was compatible with their smaller diameter and volume and suggested a decrease in either the size or number of mitochondria in each cell. The decrease in intracellular albumin and transferrin content, shown by a reduction in the amount of protein initially present in the cell, further supported a reduction in cellular contents, in keeping with similar observations by Peters \& Peters (1972), Wikramanayake et al. (1953) and Wannemacher et al. (1971). 

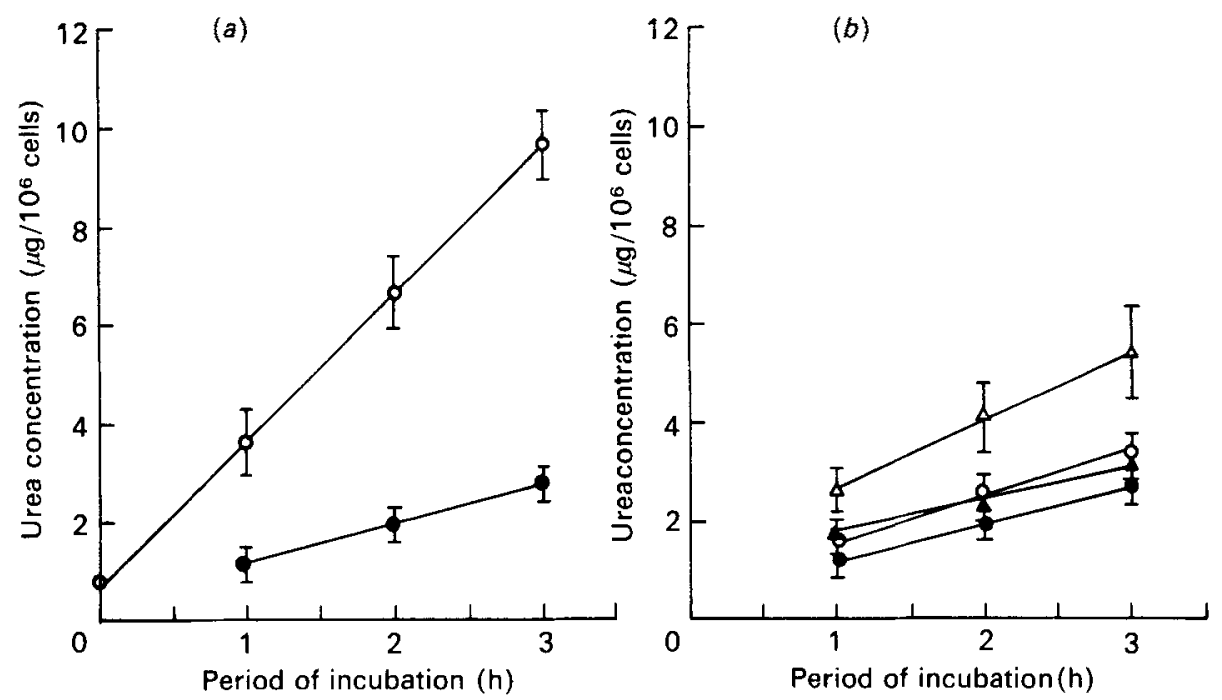

Fig. 4. Urea production by cells from normal and protein-deprived (PD) rats in Eagle's basal essential medium (BEM) $(a)$ and PD cells incubated in amino acid-supplemented BEM and Eagle's minimal essential medium (MEM) $(b)$. (a) $\bigcirc-\bigcirc$, normal cells, fourteen experiments; $-O$, PD cells, six experiments; $(b)$ - $-\mathrm{BEM}$, six experiments; $\mathrm{O}-\mathrm{O}, \mathrm{BEM}+$ ten times minimum concentration of non-essential amino acids, three experiments, $0.9 \pm 0.32 \mu \mathrm{g} / \mathrm{h}$ per $10^{6}$ cells; $\Delta-\Delta, M E M$, three experiments, $0.82 \pm 0.19 \mu \mathrm{g} / \mathrm{h}$ per $10^{8}$ cells; $\triangle-\triangle$, MEM + ten times minimum concentration of non-essential amino acids, three experiments, $1.45 \pm 0.39 \mu \mathrm{g} / \mathrm{h}$ per $10^{6}$ cells. Urea production at the beginning of incubation was too low to be measured. The points represent mean values with their standard errors indicated as vertical bars.

The marked reduction in albumin synthesis following protein deprivation has been extensively studied in vivo (James \& Hay, 1968; Kirsch et al. 1968; Haider \& Tarver, 1969; Morgan \& Peters, 1971; Jeejeebhoy, Bruce-Robertson, Ho \& Sodtke, 1973) and in the isolated perfused liver (Hoffenberg et al. 1971; Tavill et al. 1973), but the complex changes associated with malnutrition have not enabled a complete understanding of the factors involved. The use of isolated liver cells in this study enabled us to measure rates of protein synthesis per cell, and showed that albumin synthesis by cells derived from PD animals was significantly reduced to $48 \%$ of the normal control value. It is unlikely that this reduction was due to an increased loss of cell function, since cells derived from PD animals were found to maintain viability to the same extent as normal cells. However, since cell volume was decreased by a similar amount, it is probable that the rate of protein synthesis per gram of liver protein has not markedly decreased. The over-all reduction in the total amount of protein produced by livers derived from PD animals mainly reflects the decreased amount of protein produced by these smaller cells. The synthesis of transferrin in conditions of protein deprivation has not been extensively studied but Morgan \& Peters (1971) and Tavill et al. (1973) have reported a decrease in synthesis rate in the whole animal and in the isolated perfused liver. In the present study, cells derived from PD animals produced transferrin at approximately $39 \%$ of the normal control value. This value is somewhat lower than the rate of albumin synthesis found in the PD and normal cells and may indicate a disproportionate decrease in the rate of synthesis of each plasma protein.

Concomitant with the decrease in plasma protein synthesis that is found after protein deprivation, a corresponding decrease in urea synthesis has been shown in vivo and in the isolated perfused liver (Hoffenberg et al. 1971 ; Tavill et al. 1973). Other workers have suggested this is due to a reduction in urea-cycle enzyme activity (Schimke, 1962 a, $b$; Stephen \& 
Waterlow, 1968; Deosthale \& Tulpule, 1969). Urea production by cells isolated from PD animals was found to be only $25 \%$ of the value for normal cells and was only marginally increased by amino acid supplementation. Although the reduction in cell volume following protein deprivation can again be considered the main factor responsible for the reduced amount of urea produced by livers derived from PD animals, the disproportionally lower rate of urea synthesis by these cells, compared to protein synthesis, and their inability to respond to amino acid supplementation may also reflect a reduction in urea-cycle enzyme activity.

The maintenance of cell viability and the inability of essential and non-essential amino acids significantly to increase protein or urea synthesis in these cells would seem to suggest that the over-all adaptation to protein deprivation is a general reduction in cell size rather than the withdrawal of cells from protein synthesis. The ability of livers isolated from PD animals to maintain a small but predominantly aggregated polysome profile and their inability to respond to amino acid supply (Tavill et al. 1973) has led to the suggestion that adaptation occurs at a transcriptional rather than translational level, in keeping with the reduction in cellular RNA (Wikramanayake et al. 1953; Munro, Naismith \& Wikramanayake, 1953; Kido, Shimazu, Ueki \& Ogata, 1973) that is found in these conditions. The function of the cell would in this way be limited by the available protein synthetic machinery.

The authors would like to thank Miss E. G. Black and Dr A. S. Tavill for constructive criticism and Mr L. N. Louis for his expert technical assistance. A. G. G. was supported by a MRC Research Scholarship.

\section{REFERENCES}

Chandrasakharam, N., Fleck, A. \& Munro, H. N. (1967). J. Nutr. 92, 497.

Deosthale, Y. G. \& Tulpule, P. G. (1969). Indian J. Biochem. 6, 115.

Eagle, H. (1955). Science, N.Y. 122, 501.

Eagle, H. (1959). Science, N.Y. 130, 432.

East, A. G., Louis, L. N. \& Hoffenberg, R. (1973). Expl Cell Res. 76, 41.

Grant, A. G. \& Black, E. G. (1974). Eur. J. Biochem. 47, 397.

Haider, M. \& Tarver, H. (1969). J. Nutr. 99, 433.

Hoffenberg, R., Gordon, A. H. \& Black, E. G. (1971). Biochem. J. 122, 129.

Hoffenberg, R., Gordon, A. H., Black, E. G. \& Louis, L. N. (1970). Biochem. J. 118, 401.

Howard, R. B. \& Pesch, L. H. (1968). J. biol. Chem. 243, 3105.

James, W. P. T. \& Hay, A. M. (1968). J. Clin. Invest. 47, 1958.

Jeejeebhoy, K. N., Bruce-Robertson, A., Ho, J. \& Sodtke, U. (1973). Ciba Fdn Symp. 9, 217.

Kido, H., Shimazu, Y., Ueki, M. \& Ogata, K. (1973). J. Biochem. Tokyo 74, 747.

Kirsch, R., Frith, L., Black, E. \& Hoffenberg, R. (1968). Nature, Lond. 217, 578.

Mancini, G., Carbonara, A. O. \& Heremans, J. F. (1965). Immunochem. 2, 235.

Minchin-Clarke, H. G. \& Freeman, T. (1968). Clin. Sci. 35, 403.

Morgan, E. H. \& Peters, T. Jr (1971). J. biol. Chem. 246, 3500.

Munro, H. N., Naismith, D. J. \& Wikramanayake, T. W. (1953). Biochem. J. 54, 198.

Peters, T. Jr \& Peters, J. C. (1972). J. biol. Chem. 247, 3858.

Ramsden, D. N. \& Louis, L. N. (1973). J. Chromat. 86, 87.

Schimke, R. T. (1962a). J. biol. Chem. 237, 459.

Schimke, R. T. $(1962$ b). J. biol. Chem. 237, 1921.

Stephen, J. M. L. \& Waterlow, J. C. (1968). Lancet i, 118.

Tavill, A. S., East, A. G., Black, E. G., Nadkarni, D. \& Hoffenberg, R. (1973). Ciba Fdn Symp. 9, 155.

Wannemacher, R. W., Wannemacher, C. F. \& Yatvin, M. B. (1971). Biochem. J. 124, 385.

Wanson, J. C., Mosselmans, R. \& Baudhuin, P. (1973). Archs int. Physiol. Biochim. 81, 397.

Weibel, E. R., Stäubi, W., Gnägi, H. R. \& Hess, F. A. (1969). J. cell. Biol. 42, 68.

Wikramanayake, T. W., Heagy, F. C. \& Munro, H. N. (1953). Biochim. biophys. Acta 11, 566.

\section{EXPLANATION OF PLATE}

Phase-contrast micrograph of parenchymal cells isolated from normal (A) and protein-deprived (PD) rats (B) $(\times 240)$. 
British Journal of Nutrition, Vol. 38, No. 2

Plate 1
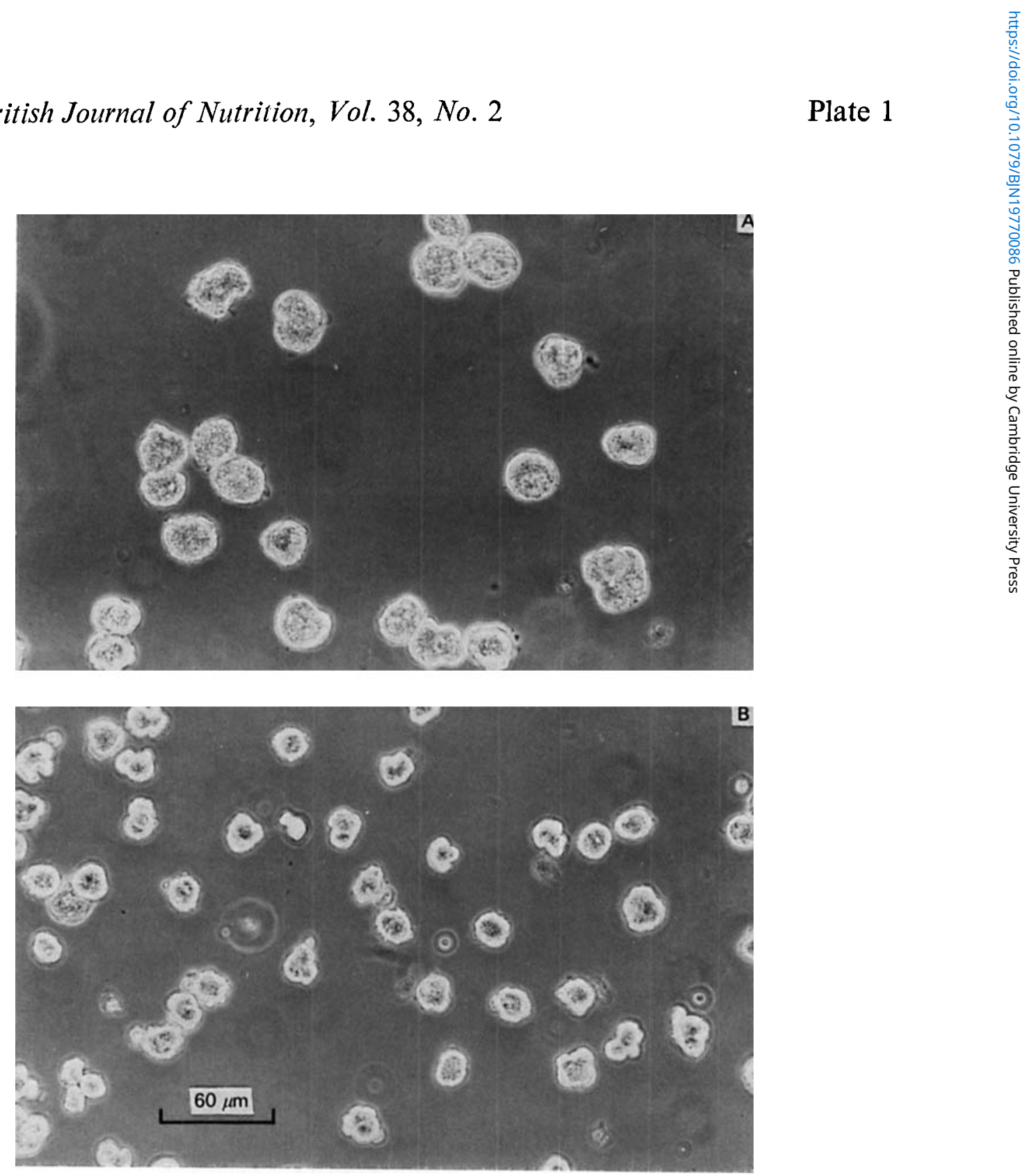

A. G. GRANT AND R. HOFFENBERG 